УДК: $338.1: 352.2$

https://doi.org/10.52058/2708-7530-2021-2(8)-224-233

Рибчинський Свген Юрійович державний та громадський діяч, м. Київ, ribchinski@gmail.com, https://orcid.org/0000-0002-3695-1903

\title{
УДОСКОНАЛЕННЯ НОРМАТИВНО-ПРАВОВОГО МЕХАНІЗМУ РЕАЛІЗАЦІЇ ДЕРЖАВНОЇ СОЦІАЛЬНОЇ ПОЛІТИКИ УКРАЇНИ
}

Анатоція. Стаття присвячена дослідженню нормативного-правового механізму реалізації державної соціальної політики, як найважливішим елементом, що спрятиме розвитку соціальної сфери загалом. Це підтверджується суттєвим посиленням уваги до неї як в офіційній державній, так і в програмноцільовій документаціях, а також практичними діями органів державної влади та усіх політичних сил. Актуальність дослідження підтверджується тим, що вирішення проблемних питань соціальної галузі має спиратися на законодавче забезпечення передумов, які $б$ забезпечили адекватний розвиток сім'ї, іiі ефективність у репродуктивному, виховному, економічному, соціальному плані, гідне втілення конституційних засад, що передбачають рівність прав жінок і чоловіків, цілеспрямовану політику зайнятості молодих людей, профілактику правопорушень, скоєних дітьми та молоддю, попередження таких негативних суспільних явищ як наркоманія, алкоголізм, дитяча бездоглядність та жебрацтво, уникнення соціального сирітства.

3'ясовано, що з метою удосконалення механізму забезпечення гідної праці та підвищення авторитету країни в європейському співтоваристві слід розглянути питання щодо посилення виконання вже ратифікованих Конвенцій, за нормами яких $є$ порушення в Україні, серед таких: Конвенція про свободу асоціації та захист права на організацію № 87, Конвенція про захист заробітної плати № 95, Конвенція про застосування принципів права на організацію i на ведення колективних переговорів № 98, Конвенція про сприяння колективним переговорам № 154, Конвенція про мінімальні норми соціального забезпечення № 102, Конвенція про захист вимог працівників у випадку неплатоспроможності роботодавця № 173.

Запропоновано прийняти в першу чергу Концепцію втілення політики євроінтеграції в Україні та Національну програму дотримання Угоди про асоціацію України та Євросоюзу. Також має проводитися певна, дуже вагома підготовка операції ратифікації 3 боку України головної міжнародної документації у галузі політики соціального спрямування. 
Ключові слова: державна політика, соціальна політика, механізм, інтеграція, Європейський Союз, влада, Концепції.

Rybchynskyi Ievhen Yuriiovych Statesman and public figure, Kyiv, ribchinski@gmail.com, https://orcid.org/0000-0002-3695-1903

\title{
IMPROVEMENT OF THE REGULATORY AND LEGAL MECHANISM OF IMPLEMENTATION OF THE STATE SOCIAL POLICY OF UKRAINE
}

\begin{abstract}
The article is devoted to the study of the normative-legal mechanism of realization of the state social policy as the most important element that will direct the development of the social sphere in general. This was confirm by a significant increase in attention to it in both the official state and program-target documentation, as well as the practical actions of public authorities and all political forces. The relevance of the study was confirm by the fact that the solution of problematic issues in the social sphere should be based on legislative prerequisites that would ensure adequate development of the family. Its effectiveness in reproductive, educational, economic, social terms men, purposeful employment policy of young people, prevention of offenses committed by children and youth, prevention of such negative social phenomena as drug addiction, alcoholism, child neglect and begging, avoidance of social orphan hood.
\end{abstract}

It was found that in order to improve the mechanism of decent work and increase the country's authority in the European community should consider strengthening the implementation of already ratified Conventions, according to which there are violations in Ukraine, including: Convention on Freedom of Association and Protection of the Right to Organize № 87, Convention on the Protection of Wages № 95, Convention on the Application of the Principles of the Right to Organize and to Bargain Collectively № 98, Convention on the Promotion of Collective Bargaining № 154, Convention on Minimum Social Security Standards № 102, Convention on the Protection of Insolvency Workers employer № 173.

It was propose to adopt, first, the Concept for the Implementation of European Integration Policy in Ukraine and the National Program for Compliance with the Association Agreement between Ukraine and the European Union. There should also be some very important preparation for the ratification operation by Ukraine of the main international documentation in the field of social policy.

Keywords: state policy, social policy, mechanism, integration, European Union, power, Concepts.

Постановка проблеми. В умовах економічного спаду соціальна сфера стає вразливою, в результаті чого виникає соціальна криза, яка легко може перерости в 
політичну. У вітчизняних умовах перед державою постає дилема: посилювати контроль над економічною і політичною сферою для стабілізації соціальної сфери або брати курс на лібералізацію. Можливі обидва варіанти, але жоден з них не гарантує успіх. В умовах кризи для зарубіжних країн так само стоїть проблема збереження колишнього рівня соціальних гарантій. Все менше піддається контролю приплив біженців та економічних мігрантів в сукупності з відсутністю значного економічного зростання звужують можливості соціально-політичних маневрів.

В даному контексті ключовою точкою взаємодії громадянського суспільства i держави є сфера соціальної політики. Соціальна політика держави є одночасно основним змістом і метою роботи уряду. Політична влада виявляється легітимною в тому випадку, якщо вона сприяє збереженню i підвищенню рівня життя суспільства, а також вирішенню соціальних проблем. У зв’язку з цим вивчення соціальної політики та відповідність ï соціальним, економічним і політичним реаліям $є$ актуальною і значущою.

Аналіз останніх досліджень і публікацій. Дану тему досліджувало багато національних та зарубіжних науковців i практиків, зокрема, Піскун К., Токарський Т., Волохов О., Бурлай Т., Прокопенко Л., Топалова Е., Калюжна Н. та інші. Науковці вивчали напрями системної трансформації соціальної політики в Україні, в умовах асоційованого членства в СС, формування соиіальної політики як основної моделі євроінтеграційного розвитку України тощзо.

Метою статті $\epsilon$ дослідження нормативно-правового механізму реалізації державної соціальної політики та способи його удосконалення.

Виклад основного матеріалу. Погоджуємося з К. Піскун, що першочергово, у контексті інтеграції України до Європейського Союзу необхідно: вдосконалити законодавчу базу, привести іiі у відповідність до міжнародних норм та стандартів; розробити виважену та чітку зовнішньоекономічну політику та поетапний план реалізації їі у життя. Однак, не потрібно очікувати миттєвого та одномоментного досягнення бажаних результатів, оскільки економічна інтеграція є тривалим та складним процесом [1].

Найважливішим зі всього взаємопов'язаного спектра нагальних завдань реформування є уточнення та обгрунтованість Концепції соціальної політики України, котрої все-таки слід очікувати як вкрай необхідну з урахуванням цьогочасних економічних i політичних змін на шляху євроінтеграції [2]. Зважаючи на ряд помилок, що були допущені у наш час, та ризики зовнішнього характеру, Україною має забезпечитися проведення досконального аналізу, на базі якого повинна розробитися програма дій на декілька років наперед. Вона, в першу чергу, повинна врахувати способи, якими можна здолати соціальноекономічну кризу у державі, описати якими конкретно заходами адаптування 
норм СС і потреб українського суспільства можна внести зміни до законодавчої системи задля надання населенню більшої економічної безпеки і незалежності, змоги зазнавати розвитку, соціального та юридичного захисту, змоги підвищити соціальний рівень життя суспільства. Слід подбати про підготовку нового молодого освіченого покоління, щоб воно могло гідно вступити у європейську спільноту. Через це слід дбати про підтримку прагнень сучасних молодих людей здобути освіту в країнах зарубіжжя i уможливити упровадження здобутих навичок і знань у вітчизняній практиці.

3 метою удосконалення механізму забезпечення гідної праці та підвищення авторитету країни в європейському співтоваристві слід розглянути питання щодо посилення виконання вже ратифікованих Конвенцій, за нормами яких $\epsilon$ порушення в Україні, серед таких: Конвенція про свободу асоціації та захист права на організацію № 87, Конвенція про захист заробітної плати № 95, Конвенція про застосування принципів права на організацію i на ведення колективних переговорів № 98, Конвенція про сприяння колективним переговорам № 154, Конвенція про мінімальні норми соціального забезпечення № 102, Конвенція про захист вимог працівників у випадку неплатоспроможності роботодавця № 173 [3].

Ураховуючи пріоритетну роль, що відіграють питання сфери зайнятості та ринку праці для реалізації політики соціальної якості, необхідно ухвалити новий Трудовий кодекс на заміну чинного Кодексу законів про працю України, ухваленого ще у 1971 р. Очевидно, що цей документ має бути розроблений 3 урахуванням нових соціально-економічних реалій $i$ завдань забезпечення соціальної якості в розвитку українського суспільства. Варто зазначити, що проект Трудового кодексу (р. № 1658 від 27.12.2014p.), який після доопрацювання 3 червня 2015 р. перебуває на розгляді у профільних комітетах парламенту України, цим критеріям не відповідає й справедливо піддається посиленій критиці експертів і профспілок [4].

Процес євроінтеграції, зокрема підписання Угоди про асоціацію - це крок українців до успішного майбутнього; це чудова перспектива України вийти на міжнародну арену. Проте будь-який процес змін $є$ нелегким і не одразу приносить позитивні результати. Ця угода не є виключенням. На сьогодні, вже є певні досягнення i зміни, але ще чимало нереалізованих перспектив. Угода про асоціацію за своїм обсягом і тематичним охопленням є найбільшим міжнародноправовим документом за всю історію України та найбільшим міжнародним договором із третьою країною, будь-коли укладеним Свропейським Союзом [5].

Україна від початку незалежності лише певною мірою успадкувала зовнішню політику, яку проводив Радянський Союз, тому швидко актуалізувалася потреба розробки нової європейської політики [6]. Починаючи 31991 р. Україною та 
Свросоюзом започаткувалися відносини, зі стрімким динамічним розвитком. Упродовж незалежного існування держави створено достатньо вагому нормативно-правову базу щодо ведення політики євроінтеграції та проведено значне число перетворень інституційно-організаційного значення в органах, метою роботи яких $є$ забезпечити координацію та реалізацію політики євроінтеграції в межах України.

Ми вважаємо, що для того, щоб глибше дослідити організаційний та нормативно-правовий супровід євроінтеграції в межах України, їх потрібно проаналізувати, спираючись на основні умовні етапи формування взаємних відносин України та Свропейського Союзу, серед яких ми можемо виокремити:

I етап - перед підписанням Угоди про партнерство i співробітництво між Україною і Свропейськими Співтовариствами та їх державами-членами - 19911994 pp.;

II етап - після ухвалення Угоди про партнерство і співробітництво між Україною i Європейськими Співтовариствами та їх державами-членами до прийняття Порядку денного асоціації-1994-2009 рр.;

III етап - підготовки до парафування, підписання, таких процесів, як ратифікація та імплементація Угоди про асоціацію між Україною та Свропейським Союзом з 2009 р. - по сьогодні.

Щодо того, на якому рівні зараз знаходиться нормативно-правове забезпечення, у нашій державі створено достатньо вагому нормативно-правову базу, що націлена формувати та реалізувати євроінтеграційну політику. Угода про партнерство і співробітництво між Україною і Свропейськими Співтовариствами та їх державами-членами, Стратегія інтеграції України до Свропейського Союзу, План дій Україна-ЄС, Порядок денний асоціації тощо заклали основу адаптаційних процесів нормативно-правового забезпечення України до Свропейського Союзу.

Крім, вищевказаних документів є багато норм, укази, розпорядження, постанови та ін., що стосується проблеми створення та втілення політики євроінтеграції в Україні.

Однак, як виявилось, прийняття такої великої кількості нормативноправових документів $є$ недостатньою умовою успішної реалізації євроінтеграційної політики, так як відсутній дійовий механізм процесу втілення в життя прийнятих законодавчих актів. На жаль, навіть гарно сформульовані закони на практиці не реалізуються. Ми погоджуємося з думкою Е. Топалової, що однією з головних причин цього є відсутність належної координації між органами влади [7].

Через те, що особливе значення для державного управління процесами євроінтеграції має саме правовий механізм, логічно буде прийняти в першу чергу:

1.Концепцію втілення політики євроінтеграції в Україні. 
Концепції втілення євроінтеграції політики в Україні, що потрібно розробити і ухвалити задля того, щоб покращити нормативно-правове забезпечення політики євроінтеграції мають вміщувати:

а) Перелік загальних положень.

б) Сучасне спрямування стану втілення курсу євроінтеграції.

в) Керування євроінтеграцією в Україні.

г) Нормативно-правовий супровід для політики євроінтеграції в Україні.

2. Національну програму дотримання Угоди про асоціацію України та Євросоюзу.

Розробку Національної програми реалізації Угоди варто розуміти як складний процес, який потребує ретельного підготовчого етапу. На ньому повинні вирішити такі задачі, як:

- вирішення проблеми чіткої структури та механізму дотримання умов, щоб ефективно втілити Національну програму втілення Угоди;

- визначення чітких повноважень підрозділів ЦОВВ у їх компетенцію при цьому належать проблеми євроінтеграції;

- підготовка та видача указу КМУ про роботу над формуванням Національної програми втілення Угоди про асоціацію 3 додаванням детального опису операцій, методів створення планів по інституційній розбудові та іншої інформації;

- розробка та затвердження методології інституційного розвитку для імплементації acquis;

- забезпечення механізму, що допомагав би відобразити фінансові витрати із втілення Національної програми виконання Угоди до запитів бюджету щодо середньострокового плану фінансування;

- проведення підготовки працівників органу координації, що відповідає за імплементацію Угоди;

- вивчення міжнародного досвіду та аналіз можливостей упровадження спецпроцедури, що передбачає розгляд парламентом (i, ймовірно, КМУ) законодавчих проектів, які поширюються на пріоритетні заходи, що торкаються імплементації Угоди.

- проведення глибокого функціонального дослідження як передумови ефективного планування інституційного розвитку владних структур та ін.;

- удосконалення стратегічного та бюджетного забезпечення втілення Національної програми виконання Угоди про асоціацію України та Євросоюзу.

3. Оновлену Стратегію інтеграції України до Євросоюзу.

Розробкою Стратегії передбачається підготовка лаконічного, чіткого формулювання документа, що $є$ змістовним та містить довгострокові пріоритети у 
відносинах, які є двосторонніми, та основні засоби управлінського та фінансового втілення цілей та задач, що визначені стратегією.

Для того, щоб підготувати загальну концепцію Стратегії, iï структури, визначення задач для органів влади, здійснення незалежних експертиз, враховуючи пропозиції, підготовку кінцевого змісту, що включає документ, потрібна спеціальна група працівників закладів науково-аналітичного характеру та залучення фахівців, що представляють громадські дослідницькі недержавні урядові центри. Запровадження Стратегії вимагає створити єдиний національний орган 3 питань координації євроінтеграції, відповідальний перед прем'єрміністром та наділений рядом певних прав та повноважень. Пункти про утворення доцільно додати у Стратегію.

Важливий аспект полягає і в тому, що Стратегією має передбачатися зв’язок з усією документацією програм у галузі євроінтеграції. Стратегія має спиратися на пріоритети співробітництва України і Свросоюзу.

Тут та у решті нормативно-правових актів повинні чітко визначатися:

- мета держполітики у галузі української євроінтеграції та іiі основна цільова направленість, пріоритетність та засади втілення;

- суб'єктний склад створення і втілення державної політики у галузі української євроінтеграції;

- їх завдання, повноваження та відповідальність, правове регулювання співдії під час формування і втілення держполітики у галузі євроінтеграції;

- механізми забезпечення втілення політики євроінтеграції, в тому числі, моделі ухвалення рішень державно-управлінського характеру, основних напрямів у інституційній політиці та ін.

Як зазначає Н. Калюжна, основними напрямами державного правового регулювання у сфері соціальної політики громадян на сьогодні мають бути [8]:

а) удосконалення законодавства України з соціальних питань для приведення його відповідно до засад та принципів Концепції соціальної держави України;

б) удосконалення національного права відповідно до норм міжнародного права для соціальної держави;

в) системне формування законодавства 3 метою впорядкування i систематизації соціальних гарантій.

Також має проводитися певна, дуже вагома підготовка операції ратифікації 3 боку України головної міжнародної документації у галузі політики соціального спрямування. Приєднання до держав, що є підписантами, передбачає готовність виконання відповідних норм і правил з регламентації розвитку суспільства та впровадження певних соціальних стандартів, якими забезпечується високий якісний рівень людської життєдіяльності.

Задля вдосконалення розподілення повноважень щодо видатків центральних 
та місцевих владних органів, а також задля формування ефективнішої моделі застосування наявного фінансового ресурсу та залучування додаткових фінансів доцільним буде вживання таких заходів, як:

1. Внесення змін у Закон України «Про державні соціальні стандарти та державні соціальні гарантії» щодо:

- введення системи стандартів, які є мінімальними, надавання соціального обслуговування суспільства, або соціальних стандартів, які є мінімальними, що (у фінансовому вираженні) повинні застосовуватися як база розподілення трансфертів, що є міжбюджетними;

- врахування місцевої специфіки при розробленні методики визначення норма соціальних видатків;

- гнучка система перетворень, яким підлягають публічні соціальні норми та соціальні гарантії, згідно зі зміною економічної системи.

2. Розроблення та прийняття законодавчих актів, що б регулювали проблеми, пов'язані з:

- спеціальним принципом спільного фінансування соціальних затрат видатки субвенцій повинна забезпечувати участь місцевого бюджету при фінансовому забезпеченні затрат, що мотивуватиме місцеві органи підтримувати певний рівень фінансового забезпечення соціального обслуговування; нормативи фінансового забезпечення повинні встановлюватися через відсоткову частку, на яку державою забезпечується усі соціальні стандарти (кожен стандарт у сфері, їх комплекс);

- залученням приватної сторони до місцевого обслуговування згідно контрактних засад уможливиться зниження витрат на надавання такого обслуговування та підвищення їх якості через впровадження ринкових конкурентних умов у сфері соціального обслуговування;

- функціонуванням регіональних позабюджетних фондів соціальної сфери, розробкою механізмів спрямовування організаціями громадського, некомерційного і комерційного фінансового потенціалу у такі фонди;

- формуванням місцевого соціального бюджету, створенням соціальних проектів, які є міжрегіональними, та їх фінансування.

Отже, будь-яка успішна євроінтеграційна політика полягає не в переліку тверджень і декларацій про вибір Свропи, а в наслідуванні принципів та цілей, що несе ця політика. 3 європейським вибором Україні відкривається ряд нових перспектив співпраці з розвиненими державами Європи, надаючи змогу досягти прогресу економіки, зміцнити позиції держави у на міжнародній арені. Це $\epsilon$ найкращий спосіб втілити національні інтереси.

Висновки. Резюмуючи зазначене, треба зауважити, що, незважаючи на наявний доволі потужний науковий потенціал і суттєвий досвід у створенні 
складного 3 технологічної точки зору продукту, держав поволі поступається своїми позиціями на ринках, де продаються високотехнологічні товари і послуги. Ідея економічної системи, в основі якої лежать знання і рушієм якої є інновації, значним чином була дискредитована в Україні через неефективність i непослідовність дій та анонс акцій, які так і не були реалізовані.

У сучасних тенденціях в галузі інновацій мало що може вселяти оптимізм, а подолати всі накопичені проблеми можна тільки, якщо буде сформовано стратегію інноваційного прогресу із передбаченими радикальними зрушеннями, перш за все, у економічному розвитку нашої країни. Необхідна передумова для цього полягає в тому, щоб розробити відповідну державну Стратегію, яка б здобула підтримку всіх зацікавлених сторін у соціумі.

\section{Лimepamypa:}

1. Піскун К. В. Соціальна складова євроінтеграції України. Актуальні проблеми міжнародних відносин. 2013. Вип. 113 (2). С. 293-295.

2. Токарський Т. Б. Соціальні орієнтири України в євроінтеграційному процесі. Вісник Львівського торговельно-економічного університету. Економічні науки. 2017. Bun. 52. C. 54-57.

3. Волохов О. Перспективи ратифікації Україною конвенцій Міжнародної організації праці URL: http://semperlegal.com/ua/novosti/ publikatsii/110-suchasni-perspektiviratifikaciikonvenciy-mop.html

4. Бурлай Т. В. Політика соціальної якості в контексті Угоди про асоціацію між Україною та СС. Економіка і прогнозування. 2015. № 4. С. 81-95.

5. Правові засади європейської та євроатлантичної інтеграції україни: досягнення та перспективи. Матеріали учасників заочної науково-практичної конференції (Львів, 31 жовтня 2017 року). Львів: НHIПП НУ «Львівська Політехніка», 2017. URL: http://www.lp.edu.ua/sites/default/files/ news/2017/7034/attachments/eu-nato_conference.kmp_inpp_ nulp._31.10.pdf.

6. Прокопенко Л. Удосконалення державного механізму європейської інтеграції. Актуальні проблеми європейської та євроатлантичної інтеграції України: матеріали 5-ї регіон. Наук.-практ. конф. 15 трав. 2008 р., м.Дніпропетровськ; за заг. Ред. Л. Л. Прокопенка. Д.: ДРІДУ НАДУ, 2008. 308 с.

7. Топалова Е. Х.Реформування публічної адміністрації в Україні: шлях до європейських стандартів. Актуальні проблеми європейської інтеграції: зб. ст. з питань європейської інтеграції та права. Одеса, 2008. Вип. 4. С. 133-144.

8. Калюжна Н. М. Розвиток національного законодавства у сфері державного управління соціальним захистом в аспекті європейської інтеграції. Наукові праці МАУП, 2012. Вип. 4 (35). C. 94-99.

\section{References:}

1. Piskun, K. V. (2013). Social`na skladova yevrointegraciyi Ukrayiny` [Social component of Ukraine's European integration]. Aktual`ni problemy`mizhnarodny`x vidnosy`n - Current issues of international relations, 113 (2), 293-295 [in Ukrainian].

2. Tokars`ky`j, T. B. (2017). Social`ni oriyenty`ry`Ukrayiny`v yevrointegracijnomu procesi 
[Social guidelines of Ukraine in the European integration process]. Visny`k L`vivs `kogo torgovel'noekonomichnogo universy`tetu. Ekonomichni nauky' - Bulletin of Lviv University of Trade and Economics. Economic sciences, 52, 54-57 [in Ukrainian].

3. Volokhov, O. Perspektyvy ratyfikatsii Ukrainoiu konventsii Mizhnarodnoi orhanizatsii pratsi [Prospects for ratification by Ukraine of the conventions of the International Labor Organization]. Retrieved from: http://semperlegal.com/ua/novosti/ publikatsii/110-suchasniperspektiviratifikacii-konvenciy-mop.html [in Ukrainian].

4. Burlai, T. V. (2015). Polityka sotsialnoi yakosti v konteksti Uhody pro asotsiatsiiu mizh Ukrainoiu ta YeS [Social quality policy in the context of the Association Agreement between Ukraine and the EU]. Ekonomika i prohnozuvannia - Economics and forecasting, 4, 81-95 [in Ukrainian].

5. Pravovi zasady yevropeiskoi ta yevroatlantychnoi intehratsii ukrainy: dosiahnennia ta perspektyvy [Legal bases of European and Euro-Atlantic integration of Ukraine: achievements and prospects] (2017): Proceedings of the participants of the correspondence scientific-practical conference. Lviv: NNIPP NU «Lvivska Politekhnika», 2017. Retrieved from: http://www.lp.edu.ua/sites/default/files/news/2017/7034/attachments/eu-nato_conference.kmp_inpp_ nulp._31.10.pdf. [in Ukrainian].

6. Prokopenko, L. (2008). Udoskonalennia derzhavnoho mekhanizmu yevropeiskoi intehratsii [Improving the state mechanism of European integration]. Aktualni problemy yevropeiskoi ta yevroatlantychnoi intehratsii Ukrainy - Current issues of European and Euro-Atlantic integration of Ukraine: Proceedings of the 5th region. scientific-practical conf. Dnipropetrovsk: DRIDU NADU [in Ukrainian].

7. Topalova, E. Kh. (2008). Reformuvannia publichnoi administratsii v Ukraini: shliakh do yevropeiskykh standartiv [Reforming public administration in Ukraine: the path to European standards]. Aktualni problemy yevropeiskoi intehratsii: zb. st. z pytan yevropeiskoi intehratsii ta prava - Current issues of European integration: Coll. Art. on European integration and law, 4, 133-144. [in Ukrainian].

8. Kaliuzhna, N. M. (2012). Rozvytok natsionalnoho zakonodavstva u sferi derzhavnoho upravlinnia sotsialnym zakhystom $\mathrm{v}$ aspekti yevropeiskoi intehratsii [Development of national legislation in the field of public administration of social protection in the aspect of European integration]. Naukovi pratsi MAUP - Scientific works of IAPM, 4 (35), 94-99 [in Ukrainian]. 